\title{
Wound healing in Piaractus mesopotamicus supplemented with chromium carbochelate and Saccharomyces cerevisiae
}

\section{Cicatrização cutânea em Piaractus mesopotamicus suplementados com carboquelato de cromo e Saccharomyces cerevisiae}

\author{
Neida Lucas BORTOLUZZI'; Marcelo Pardi de CASTRO루 ${ }^{1}$ Gustavo da Silva CLAUDIANO ${ }^{1}$; \\ Jefferson YUNIS-AGUINAGA²; Victor Alexander CUEVA-QUIROZ²; \\ Julieta Rodini Engrácia de MORAES ${ }^{1,2}$; Flávio Ruas de MORAES ${ }^{1,2}$
}

\footnotetext{
${ }^{1}$ Universidade Estadual Paulista Júlio de Mesquita Filho, Departamento de Patologia Veterinária, Jaboticabal - São Paulo, Brazil

${ }^{2}$ Universidade Estadual Paulista Júlio de Mesquita Filho, Centro de Aquicultura, Jaboticabal - São Paulo, Brazil
}

\begin{abstract}
Wound healing and tissue repair are necessary to ensure survival and health of any organism. The aim of this study was to investigate the impact of supplementation with chromium carbochelate (CC) and Saccharomyces cerevisiae (SC) on wound healing in tropical teleost fish Piaractus mesopotamicus. Thus, fish were distributed into four groups: a) control (without supplementation); b) supplemented with $18 \mathrm{mg} / \mathrm{kg}$ of chromium carbochelate; c) supplemented with $0.3 \%$ of S. cerevisiae and d) supplemented with an association of both supplements. After 105 days of feeding, full-thickness skin incisions $(2.0 \times 1.0 \times 0.25 \mathrm{~cm})$ were performed removing epidermis and dermis. Macroscopic and histologic observations were carried out at 1, 3, 7, 14,21,28, and 35 days after wounding to monitor the healing rate. Opposing fronts advanced gradually and faster each day demonstrating a progressive increase in the healing process over time. The inflammatory process was exacerbated and expansive, with an increase in mucous cells and chromatophores. Although no significant differences were observed between groups on wound retraction and microscopic parameters, fish supplemented with CC and SC showed faster re-epithelialization, greater degree of organization of collagen fibers, and higher neovascularization. We concluded that supplementation with S. cerevisiae and chromium carbochelate improves specific aspects of cutaneous healing process in pacu.
\end{abstract}

Keywords: Tissue repair. Chromium carbochelate. Saccharomyces cerevisiae. Freshwater fish. Pacu.

\section{Resumo}

A cicatrização e reparação de tecidos são mecanismos essenciais para garantir a sobrevivência e saúde de qualquer indivíduo. O objetivo deste trabalho foi avaliar o impacto da suplementação com carboquelato de cromo (CC) e Saccharomyces cerevisiae (SC) sobre a cicatrização no peixe tropical Piaractus mesopotamicus. Para isto, os peixes foram distribuídos em quatro grupos: controle (sem tratamento), suplementados com $18 \mathrm{mg} / \mathrm{kg}$ de carboquelato de cromo, 0,3\% de S. cerevisiae e associação de ambos os suplementos. Após 105 dias de alimentação, foram realizadas incisões na pele de espessura completa $(2,0$ x 1,0 x 0,25 cm) removendo epiderme e derme. Avaliações macroscópicas e microscópicas foram realizadas 1, 3, 7, 14,21, 28 e 35 dias após a indução das feridas, para monitorar a taxa de cicatrização. As bordas opostas das feridas avançaram gradualmente a cada dia, demonstrando o aumento progressivo do processo de cicatrização ao longo do tempo. O processo inflamatório foi exacerbado e expansivo, com aumento no número de células mucosas e cromatóforos. Apesar deste processo, não foram observadas diferenças significativas na retração das feridas e nos parâmetros microscópicos entre os grupos. Peixes suplementados com CC ou Sc apresentaram rápida reepitelização, maior grau de organização de fibras colágenas e de neovascularização inicial. Concluiu-se que a suplementação com S. cerevisiae ou carboquelato de cromo melhora aspectos específicos do processo cicatricial no pacu.

Palavras-chave: Reparo tecidual. Cromo trivalente. Saccharomyces cerevisiae. Peixe de água doce. Pacu. 
Correspondence to:

Flávio Ruas de Moraes

Universidade Estadual Paulista Júlio de Mesquita Filho,

Faculdade de Ciências Agrárias e Veterinárias, Departamento

de Patologia Veterinária

Via de Acesso Prof. Paulo Donato Castellane, s/n

CEP 14884-900, Jaboticabal, SP, Brasil

email: fruasmoraes@gmail.com

Received: 12/12/2016

Approved: 09/06/2017

\section{Introduction}

Skin lesions in fish have several causes: infection, parasites, inadequate transport, fights due to high stocking density, and presence of sharp structures in tanks and cages. The skin of fish is the main defense organ against environmental hazards (BANERJEE; MITTAL, 1999) and its ability to quickly replace damaged or dead cells is essential to prevent blood loss, maintain the integrity of the surrounding tissue and prevent pathogen invasion (GUERRA et al., 2008; RICHARDSON et al., 2013).

Wound healing is a complex process that consists of several events, which can overlap each other, including the formation of hemorrhagic clots, inflammation, formation of granulation tissue, angiogenesis, re-epithelialization, wound contraction, and extracellular matrix remodeling (GUERRA et al., 2008; SCHMIDT et al., 2016).

Wound healing process in teleost fish may vary depending on the species. Wound closure is accomplished by the movement of migratory fronts (epidermis from wound borders), which starts as early as 12 hours after injury induction in the African catfish, Clarias gariepinus (GUERRA et al., 2008). Full re-epithelialization is completed in less than $24 \mathrm{~h}$ in pacu (Piaractus mesopotamicus), achieved by expansion of nearby healthy epidermal cells (MORAES et al., 2003). However, tilapia presents a slower healing process with complete re-epithelialization 14 days after wounding (MORAES et al., 2011).

There are several studies about the effect of feed supplementation on growth, survival rate, immune parameters, and disease resistance of fish (AKHTER et al., 2015; YUNIS-AGUINAGA et al., 2015, 2016; DAWOOD; KOSHIO, 2016). However, studies on the implications of feed supplementation on wound healing in fish are scarce. Supplementation with increasing amounts of vitamin C accelerated the cutaneous injuries repair in pacu (MORAES et al., 2003) and tilapia (MORAES et al., 2011). Dietary supplementation with vitamin $\mathrm{C}$ also benefits macrophage activity on foreign-body inflammation (BELO et al., 2012).
Other products as $\beta$-glucans applied by bath have resulted in significantly faster wound retraction in carp (PRZYBYLSKADIAZ et al., 2013), but limited effect on healing of skeletal muscle tissue in rainbow trout (SCHMIDT et al., 2016).

Chromium carbochelate as a source of trivalent chromium (FUJIMOTO et al., 2005; CASTRO et al., 2014a, $2014 \mathrm{~b}$ ) and the yeast Saccharomyces cerevisiae (REQUE et al., 2010; SALVADOR et al, 2012) are noteworthy dietary supplements in fish due to their properties. Trivalent chromium strengthens the action of insulin (MOWAT, 1997) and facilitates its attachment to its receptor on the cell surface, increasing cells sensitivity to glucose (LUKASKI, 2000). Supplementation with trivalent chromium increased serum immunoglobulin concentrations (ALKAHEM, 1994), reduced levels of cortisol and glycemia, and restored hepatic glycogen improving acute inflammatory response induced by bacteria (FUJIMOTO et al., 2005; CASTRO et al., 2014a, 2014b). Supplementation with S. cerevisiae improved weight gain, growth rate, and disease resistance in tilapia challenged with Aeromonas hydrophila and Streptococcus agalactiae by increasing the innate immune response (ABDEL-TAWWAB et al., 2008; REQUE et al., 2010; SALVADOR et al., 2012, 2013).

Thus, the aim of this study was to evaluate the effects of chromium carbochelate and S. cerevisiae supplementation on the healing process of experimental-induced cutaneous wounds in P. mesopotamicus.

\section{Material and methods}

\section{Animals and ethics statement}

Apparently healthy pacus (Piaractus mesopotamicus) from the same spawn, mean weight $317.56 \pm 88.29 \mathrm{~g}$ $(\mathrm{n}=336)$, were distributed into 28 fiber boxes $(250 \mathrm{~L}$, $\mathrm{n}=12$ ) supplied with free-running water from an artesian well at a flow rate of $1 \mathrm{~L} / \mathrm{min}$ with permanent aeration. Fish were acclimatized for 15 days prior to use and received commercial feed without supplementation ( $3 \%$ of the biomass, 28\% crude protein and $3800 \mathrm{kcal}$ gross energy). Ethical protocol for this study was approved by the Ethics Committee of CEUA-UNESP under protocol number 016402-07 in accordance with the guidelines for care and use of laboratory animals provided by Brazilian laws.

\section{Experimental design}

After the adaptation period, fish were randomly distributed in a $4 \times 7$ factorial arrangement, with four 
groups: $\mathrm{T} 1$ = control (diet without supplementation); $\mathrm{T} 2=$ supplemented with $0.3 \%$ of Saccharomyces cerevisiae cell wall (SC); T3 = supplemented with diet of $18 \mathrm{mg}$ of chromium carbochelate / kg (CC); T4 = association $(\mathrm{CC}+\mathrm{SC})$. Concentrations of $\mathrm{CC}$ and SC were based on previous studies (FUJIMOTO et al., 2005; REQUE et al., 2010; SALVADOR et al., 2012). After 105 days of supplementation, surgical skin wounds were performed. Then, macroscopic and histologic evaluations were performed at 1, 3, 7, 14, 21, 28 , and 35 days post induction (DPI).

\section{Diets, feeding and management}

The basal diet was free of chromium and yeast, formulated according to Table 1 and subjected to chemicalbromatological composition analyses (CASTRO et al., 2014a). Four different diets were developed: added with CC, SC, both, or none (control). Feed samples were pelletized, packed, and stored at $-18^{\circ} \mathrm{C}$. The fish received feed twice a day at apparent satiety. Water quality was determined weekly using multiprobe system YSI MPS 556 (YSI, Yellow Springs, USA) and colorimetric test kit (La Motte, Washington, USA). Parameters remained within the adequate range for fish comfort (BOYD, 1990), dissolved oxygen $=4.3 \pm 0.8 \mathrm{mg} / \mathrm{L}$; temperature $=30.2 \pm 0.8^{\circ} \mathrm{C} ; \mathrm{pH}$ $=8.0 \pm 0.5$, electric conductivity $=36.8 \pm 44.5 \mu \mathrm{S} / \mathrm{cm}$ and total ammonia $=0.21 \pm 0.03 \mathrm{mg} / \mathrm{L}$.

Table 1 - Percentage and chemical-bromatological composition of the basal diet

\begin{tabular}{lc}
\hline Ingredients & $\%$ \\
\hline Ground corn & 25.0 \\
Soy bran & 24.0 \\
Rice bran & 15.6 \\
Wheat bran & 14.0 \\
Fish flour & 19.0 \\
Crude soybean oil & 1.0 \\
Vitamin and mineral mix & \\
supplement (kg/product) & 0.7 \\
\hline
\end{tabular}

\begin{tabular}{|c|c|}
\hline \multicolumn{2}{|l|}{ Proximal composition } \\
\hline Crude protein (\%) & 28.3 \\
\hline Ether extract (\%) & 6.0 \\
\hline Crude fiber (\%) & 6.8 \\
\hline Mineral material (\%) & 8.0 \\
\hline Moisture (max) & 8.6 \\
\hline Ca:P ratio & $1.4: 1.25$ \\
\hline \multicolumn{2}{|c|}{$\begin{array}{l}{ }^{*} \text { Composition of vitamin-mineral supplement: calcium (max) 1.8\%, phosphorus } \\
\text { (min) } 0.6 \% \text {; copper } 15 \mathrm{mg} / \mathrm{kg} \text {, I 7,5 mg/kg, iron } 150 \mathrm{mg} / \mathrm{kg} \text {, manganese } 105 \mathrm{mg} / \\
\mathrm{kg} \text {, selenium } 0.22 \mathrm{mg} / \mathrm{kg} \text {, zinc } 225 \mathrm{mg} / \mathrm{kg} \text {, folic acid } 1.5 \mathrm{mg} / \mathrm{kg} \text {, pantothenic acid } \\
30 \mathrm{mg} / \mathrm{kg} \text {, BHT } 125 \mathrm{mg} / \mathrm{kg} \text {, choline } 225 \mathrm{mg} / \mathrm{kg} \text {, vitamin A } 4500 \mathrm{UI} / \mathrm{kg} \text {, vitamin } \\
\mathrm{B}_{1} 9 \mathrm{mg} / \mathrm{kg} \text {, vitamin } \mathrm{B}_{12} 30 \mathrm{mg} / \mathrm{kg} \text {, vitamin B } 12 \mathrm{mg} / \mathrm{kg} \text {, vitamin B6 } 4.5 \mathrm{mg} / \mathrm{kg} \text {, } \\
\text { vitamin C } 300 \mathrm{mg} / \mathrm{kg} \text {, vitamin D3 } 4500 \mathrm{UI} / \mathrm{kg} \text {, vitamin E } 250 \mathrm{UI} / \mathrm{kg} \text {, vitamin K } \\
9 \mathrm{mg} / \mathrm{kg} \text {, niacin } 150 \mathrm{mg} / \mathrm{kg} \text {, biotin } 0.15 \mathrm{mg} / \mathrm{kg}\end{array}$} \\
\hline
\end{tabular}

\section{Wounding}

Animals were anaesthetized by immersion in $100 \mathrm{mg} / \mathrm{L}$ benzocaine solution (E1501, Sigma-Aldrich, St. Louis, USA) (NEIFFER; STAMPER, 2009). Wound induction technique was the same as described by Moraes et al. $(2003 ; 2011)$ with lesion size corresponding to $3 \%$ of fish body surface. The vertices of the experimental wounds $(2.0 \times 1.0 \times 0.25 \mathrm{~cm})$ were outlined using a sterile plastic template on the left lateral region of the fish. A full thickness flap of skin was removed by cutting epidermis plus dermis with sharp scalpel. Hemorrhage, when necessary, was controlled by applying pressure with sterile cotton gauze. No fish died due to the experimental wounding.

\section{Sampling}

Euthanasia was performed in twelve fish at each time by overdose of benzocaine. Injury retraction was evaluated macroscopically and then samples of skin were taken for histopathology analysis at 1, 3, 7, 14, 21, 28, and 35 days after the induction of injuries samples in all groups.

\section{Macroscopic examination}

Wound retraction area was evaluated macroscopically by an image analysis system AxioVision LE (Zeiss, Jena, Germany) using fixed focal distance of $22.0 \mathrm{~cm}$, which allowed equal wound size measurements. The results were calculated as follows:

$$
\begin{gathered}
\text { WRA = IA - FA / IA x } 100 \\
\text { where: WRA = Wound retraction area; } \\
\text { IA = Initial area; FA = Final Area. }
\end{gathered}
$$

The percentage of wound retraction considered the retraction area compared to the initial area of the wound (RAMASAMY; SHANMUGAM, 2015).

\section{Histological evaluation}

The collection of skin sample was performed by excising $1.0 \mathrm{~cm}$ before wound edge, taking fragments of skin and muscle $(4.0 \times 6.0 \times 2.0 \mathrm{~cm})$. After fixation in Bouin's solution or $10 \%$ formalin saline, the material was kept in $70 \%$ alcohol until the time of inclusion. The material fixed in Bouin's was processed in paraffin and cut in $5 \mu \mathrm{m}$-thick sections. Fragments fixed in formalin were mounted in historesin (7022 31731, Leica Microsystems, Wetzlar, Germany) and cut in $3 \mu \mathrm{m}$ sections. The obtained sections were stained with hematoxylin and eosin and 
Masson's Trichrome stain to observe the deposition of collagen fibers. Techniques were performed according to Bancroft and Gamble (2002). The examination was performed under an optical microscope (BX51, Olympus Corporation, Tokyo, Japan). Images were taken using a digital camera (DP 72, Olympus Corporation). Five fields were randomly selected on each slide at 400x magnification for evaluation of the conditions of epithelium, measuring of epidermal and dermal thickness, counting number of mucous cells, inflammatory cells, and neovascularization in each time and group. Lesions were measured using the image analyzer cellSens Standard 1.5 (Olympus Corporation).

\section{Statistical analysis}

Data were analyzed by one-way variance (ANOVA) and Tukey test for multiple comparisons of means $(\mathrm{P}<0.05)$ considered statistically significant. Statistical analysis was performed using Prism 5.01 (GraphPad,
La Jolla, USA). Results were expressed as mean \pm standard error of mean (SE).

\section{Results and discussion}

After wound infliction, skin edges became dark at 1 DPI. No differences in wound color were seen between groups until 7 DPI. After 14 DPI, wounds appeared dark at the edges with yellowish mid-central area and bright red center in control, SC, and CC+SC groups. CC group showed the same characteristics, however, wound edges became rounder due to earlier scale growth (Figure 1). Skin darkening on the region surrounding the wound has been reported in common carp Cyprinus carpio (IGER; ABRAHAM, 1990), scalyfish Channa striata after $1 \mathrm{~h}$ post-injury (BANERJEE; MITTAL, 1999), African catfish 12 hours after wounding (GUERRA et al., 2008), and Indian major carp, Labeo rohita, $2 \mathrm{~h}$ post-injury (RAI et al., 2012). This characteristic suggests changes in chromatophore activity (RAI et al., 2012).

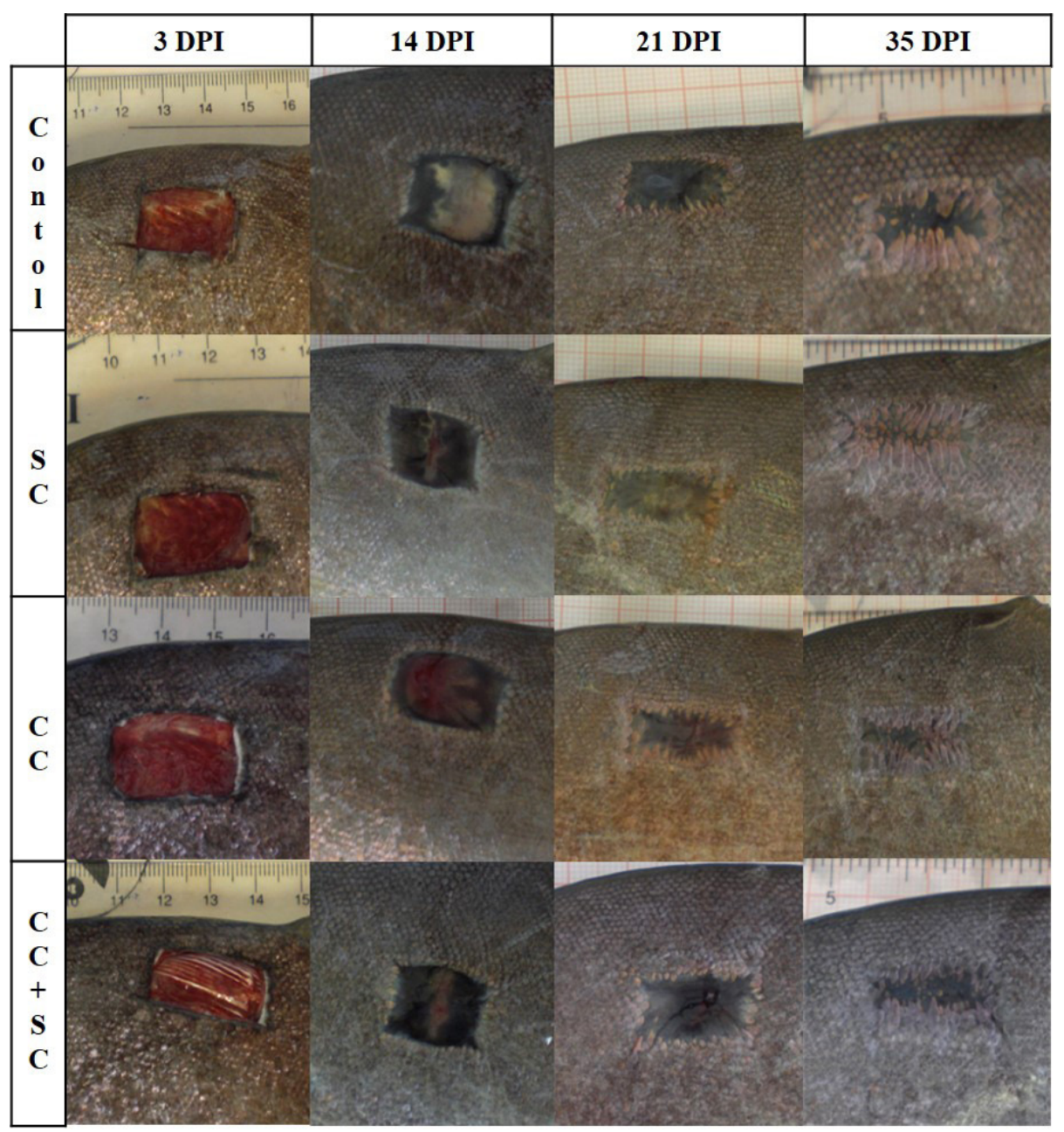

Figure 1 - Photographs of wounds taken on different days after injury (DPI). Control: non-supplemented fish, SC: supplemented with $0.3 \%$ of S. cerevisiae, CC: supplemented with $18 \mathrm{mg} / \mathrm{kg}$ of chromium carbochelate, CC+SC: supplemented with both feed additives 
At 35 DPI, supplemented groups showed more evident growth of scales in the wound area, however full growth of scales was not achieved within 5-week observation period (Figure 1). There were no significant differences on wound retraction $(p>0.05)$ between groups, only between days. The healing progression increased gradually $(\mathrm{p}<0.05)$ between days 3, 7, and 35. After day 14, healing speed remained constant without showing statistical difference $(\mathrm{p}>0.05)$ until 35 DPI $(\mathrm{p}<0.05$, Table 2$)$.

The wound retraction began in all groups at $3 \mathrm{DPI}$, same as described by Moraes et al. (2011) in tilapias with injuries of the same size and supplemented with vitamin E. The present result differs from that observed by Moraes et al. (2003), who reports wound retraction 14 days after wounding in the same species supplemented with 500 $\mathrm{mg}$ of vitamin C. Although there were no significant differences in wound retraction between groups ( $p>0.05$ ), a faster response was noticed in animals supplemented with chromium carbochelate or S. cerevisiae. However, the association of both evidenced values similar to those presented by the control group (Table 2).

This improvement was observed through microscopic evaluation, showing that complete re-epithelialization was achieved after $24 \mathrm{~h}$ in supplemented fish and 3 DPI in control group. Studies investigating the effect of dietary vitamin $\mathrm{C}$ on wound healing conducted in rainbow trout (WAHLI et al., 2003) and tilapia (MORAES et al., 2011) with similar-size skin wounds reported that re-epithelialization starts on the third day post-wounding, with no difference between supplemented and non-supplemented fish. Epithelial cells evidenced swelling and elongation in direction to the center of the wound as observed in the cichlid fish Hemichromis bimaculatus (QUILHAC; SIRE, 1999) and tilapia (MORAES et al., 2011). Early reepithelialization acts as a physical barrier and prevents animal from exposure to opportunistic pathogens and osmotic imbalance disequilibrium (MORAES et al., 2003).

Complete re-epithelialization was achieved before inflammation reached its highest severity and before complete removal of cellular debris. In Cyprinus carpio, re-epithelialization overlaps with phagocytosis of cellular debris (IGER; ABRAHAM, 1990). In zebrafish, Danio rerio, re-epithelialization starts before inflammation and in absence of blood clotting, inflammation, or granulation tissue. In addition, re-epithelialization in zebrafish is independent of wound debridement by neutrophils and chemotactic signals from macrophages (RICHARDSON et al., 2013).

Epidermal thickness did not differ between groups, but it did between times (P 0.05, Table 3). Epidermis was thicker at 21 DPI and showed no difference $(p>0.05)$ at 1 , 3,7 , and 35 DPI, in contrast with reports by Banerjee and Mittal (1999), who found an initial decrease in epidermal thickness between $16 \mathrm{~h}$ and $30 \mathrm{~h}$, followed by an increase in subsequent stages in a scaly fish.

Dermis reorganization started at 3 DPI (Figure 2) and was completed on day 14 . There were no differences in dermis thickness ( $p>0.05$; Table 3 ) between groups, only between times. Dermal thickness increased progressively reaching his maximum at $21 \mathrm{DPI}$ and kept significantly thicker even at the last sampling time when compared to 1 DPI. Difference at later stages of healing process, between 28 and 35 DPI, was due to decrease in thickness, with values similar to those found in days 3 and 7 , which can be attributed to the degree of inflammation (Figure 2A and B). Dermal thickness increase during early stages of wound healing has also been reported by Guerra et al. (2008).

The inflammatory process expanded faster to the muscles with presence of chromatophores in groups SC, CC, and SC+CC in relation to control, where the inflammatory process was restricted to the dermis (Figure

Table 2 - Wound retraction area $\left(\mu \mathrm{m}^{2}\right)$ during different times post-injury in Piaractus mesopotamicus: non-supplemented (control), supplemented with $0.3 \%$ of Saccharomyces cerevisiae (SC), supplemented with $18 \mathrm{mg} / \mathrm{kg}$ of chromium carbochelate (CC), and supplemented with both additives $(\mathrm{CC}+\mathrm{SC})$

\begin{tabular}{lcccccc}
\hline \multirow{2}{*}{ Treatments } & \multicolumn{5}{c}{ Sampling times } \\
\cline { 2 - 7 } & $\mathbf{3 ~ D P I}$ & $\mathbf{7 ~ D P I}$ & $\mathbf{1 4}$ DPI & $\mathbf{2 1}$ DPI & $\mathbf{2 8 ~ D P I}$ & $\mathbf{3 5}$ DPI \\
\hline Control & $104.7 \pm 44.7^{\mathrm{d}}$ & $116.1 \pm 44.7^{\mathrm{c}}$ & $128.4 \pm 16.9^{\mathrm{b}}$ & $130.4 \pm 16.9^{\mathrm{b}}$ & $119.1 \pm 16.9^{\mathrm{b}}$ & $146.3 \pm 16.9^{\mathrm{a}}$ \\
SC & $109.4 \pm 21.5^{\mathrm{d}}$ & $136.6 \pm 21.5^{\mathrm{c}}$ & $115.5 \pm 16.9^{\mathrm{b}}$ & $129.8 \pm 16.9^{\mathrm{b}}$ & $138.0 \pm 16.9^{\mathrm{b}}$ & $221.1 \pm 16.9^{\mathrm{a}}$ \\
CC & $123.3 \pm 44.3^{\mathrm{d}}$ & $128.3 \pm 25.2^{\mathrm{c}}$ & $111.1 \pm 16.9^{\mathrm{b}}$ & $139.1 \pm 16.9^{\mathrm{b}}$ & $141.8 \pm 16.9^{\mathrm{b}}$ & $211.4 \pm 16.9^{\mathrm{a}}$ \\
CC + SC & $91.3 \pm 31.1^{\mathrm{d}}$ & $115.7 \pm 25.0^{\mathrm{c}}$ & $115.3 \pm 16.9^{\mathrm{b}}$ & $118.9 \pm 16.9^{\mathrm{b}}$ & $146.2 \pm 16.9^{\mathrm{b}}$ & $167.7 \pm 16.9^{\mathrm{a}}$ \\
\hline
\end{tabular}

Data is expressed as mean \pm standard deviation $(n=12)$. Different letters on sampling times of the same group show significant difference by Tukey test ( $<<0.05)$. No significant differences were found on the same sampling time of different treatments $(\mathrm{p}>0.05)$. DPI: Days post injury 
Table 3 - Evolution of epidermal and dermal thickness, number of mucous cells, and neo-vascularization after experimental wounding in Piaractus mesopotamicus: nonsupplemented (C), supplemented with 0.3\% of Saccharomyces cerevisiae (Sc), supplemented with $18 \mathrm{mg} / \mathrm{kg}$ of chromium carbochelate (CC), and supplemented with both additives (CC+SC)

\begin{tabular}{|c|c|c|c|c|c|c|c|c|}
\hline \multirow{2}{*}{ Parameters* } & \multirow{2}{*}{ Groups } & \multicolumn{7}{|c|}{ Sampling times } \\
\hline & & $1 \mathrm{DPI}$ & 3 DPI & 7 DPI & 14 DPI & 21 DPI & 28 DPI & 35 DPI \\
\hline \multirow{4}{*}{ Epidermis $(\mu \mathrm{m})$} & C & $69.6 \pm 21.0_{b}$ & $70.0 \pm 8.8_{b}$ & $58.6 \pm 5.2_{b}$ & $94.2 \pm 12.1_{a}$ & $86.6 \pm 9.8_{a}$ & $102.4 \pm 10.2_{a}$ & $90.7 \pm 9.3_{b}$ \\
\hline & SC & $50.3 \pm 8.5_{b}$ & $84.0 \pm 10.1_{b}$ & $69.8 \pm 13.8 \mathrm{~b}$ & $96.5 \pm 13.0 \mathrm{a}$ & $86.4 \pm 5.6_{a}$ & $96.2 \pm 18.3_{\mathrm{a}}$ & $81.9 \pm 8.1_{b}$ \\
\hline & $\mathrm{CC}$ & $57.1 \pm 13.3_{b}$ & $62.6 \pm 10.1_{b}$ & $79.0 \pm 11.6_{b}$ & $75.0 \pm 10.1_{a}$ & $117.8 \pm 7.3_{a}$ & $98.2 \pm 12.2_{a}$ & $74.0 \pm 5.3_{b}$ \\
\hline & $\mathrm{CC}+\mathrm{SC}$ & $57.9 \pm 9.5_{b}$ & $85.2 \pm 4.0_{b}$ & $73.0 \pm 11.6_{b}$ & $94.5 \pm 9.6$ & $100.6 \pm 9.1_{a}$ & $82.4 \pm 8.8$ & $69.8 \pm 6.6_{b}$ \\
\hline \multirow{4}{*}{ Dermis $(\mu \mathrm{m})$} & C & $79.1 \pm 32.5_{c}$ & $547.6 \pm 50.3_{b}$ & $1084.3 \pm 37.1_{a}$ & $824.9 \pm 59.9_{b}$ & $1269.3 \pm 103.4_{a}$ & $1614.2 \pm 135.1_{a}$ & $1116.7 \pm 87.3_{\mathrm{ab}}$ \\
\hline & SC & $88.8 \pm 13.4_{c}$ & $444.4 \pm 49.3 \mathrm{~b}$ & $987.3 \pm 85.5$ & $1038.5 \pm 126.4_{b}$ & $1457.8 \pm 91.0_{a}$ & $1429.4 \pm 164.0_{a}$ & $1248.3 \pm 79.2_{\mathrm{ab}}$ \\
\hline & CC & $102.2 \pm 16.0_{c}$ & $647.8 \pm 119.8_{b}$ & $848.6 \pm 84.9 a$ & $1602.1 \pm 137.3_{b}$ & $1620.0 \pm 63.8_{a}$ & $1493.8 \pm 85.7$ & $1269.4 \pm 79.5_{\mathrm{ab}}$ \\
\hline & $\mathrm{CC}+\mathrm{SC}$ & $123.8 \pm 25.4_{c}$ & $468.3 \pm 40.8_{b}$ & $1061.0 \pm 79.1_{a}$ & $1057.6 \pm 129.2_{b}$ & $1602.6 \pm 103.2_{a}$ & $1278.8 \pm 85.7$ & $1005.6 \pm 67.8_{\mathrm{ab}}$ \\
\hline \multirow{4}{*}{ Mucous cells } & C & $3.1 \pm 20.1_{b}$ & $52.3 \pm 28.0_{b}$ & $60.0 \pm 36.1_{b}$ & $139.8 \pm 29.6_{b}$ & $159.6 \pm 27.8_{a}$ & $295.8 \pm 26.4_{a}$ & $181.2 \pm 29.4_{a}$ \\
\hline & SC & $15.7 \pm 36.4_{b}$ & $29.6 \pm 29.5_{b}$ & $74.5 \pm 31.8_{b}$ & $122.4 \pm 43.6_{b}$ & $220.8 \pm 31.8_{a}$ & $211.0 \pm 28.2_{a}$ & $262.8 \pm 27.8_{a}$ \\
\hline & CC & $50.7 \pm 33.7 b$ & $52.8 \pm 29.9_{b}$ & $103.1 \pm 40.0_{b}$ & $282.0 \pm 36.7_{b}$ & $210.6 \pm 28.2_{a}$ & $241.4 \pm 29.8 a$ & $257.6 \pm 30.1_{\mathrm{a}}$ \\
\hline & $\mathrm{CC}+\mathrm{SC}$ & $16.9 \pm 14.9_{b}$ & $63.3 \pm 32.1_{b}$ & $112.8 \pm 36.9 b$ & $125.7 \pm 29.5_{b}$ & $230.1 \pm 30.3 \mathrm{a}$ & $273.4 \pm 36.8 \mathrm{a}$ & $203.2 \pm 30.3_{a}$ \\
\hline \multirow{4}{*}{$\begin{array}{l}\text { Neovascularization } \\
1\end{array}$} & C & $31.3 \pm 59.4_{d}$ & $172.5 \pm 37.8_{c}$ & $511.4 \pm 42.8$ a & $741.1 \pm 49.6_{\mathrm{ab}}$ & $401.9 \pm 35.8_{\mathrm{ab}}$ & $375.2 \pm 45.9_{b}$ & $228.9 \pm 53.9_{b}$ \\
\hline & SC & $74.3 \pm 54.2_{d}$ & $234.8 \pm 40.5_{c}$ & $529.6 \pm 49.9_{a}$ & $566.3 \pm 59.7 \mathrm{ab}$ & $404.7 \pm 43.3_{\mathrm{ab}}$ & $252.1 \pm 46.3_{b}$ & $287.7 \pm 40.4_{b}$ \\
\hline & CC & $42.1 \pm 67.0_{d}$ & $121.3 \pm 46.6_{c}$ & $508.5 \pm 5.5$ & $149.7 \pm 67.6_{\mathrm{ab}}$ & $413.1 \pm 38.2_{\mathrm{ab}}$ & $330.3 \pm 35.8_{b}$ & $319.1 \pm 46.5_{b}$ \\
\hline & $\mathrm{CC}+\mathrm{SC}$ & $51.3 \pm 53.5_{d}$ & $200.8 \pm 45.7_{c}$ & $614.9 \pm 45.5_{a}$ & $367.0 \pm 40.0_{\mathrm{ab}}$ & $405.8 \pm 40.2_{\mathrm{ab}}$ & $305.3 \pm 42.5_{b}$ & $337.5 \pm 42 ._{b}$ \\
\hline
\end{tabular}

${ }^{*}$ Data is expressed as mean \pm standard deviation $(n=12)$. Different letters on different times of the same group indicate significant difference by Tukey test. There were no significant differences between groups. ${ }_{1}$ Data was transformed to log. DPI: days post injury
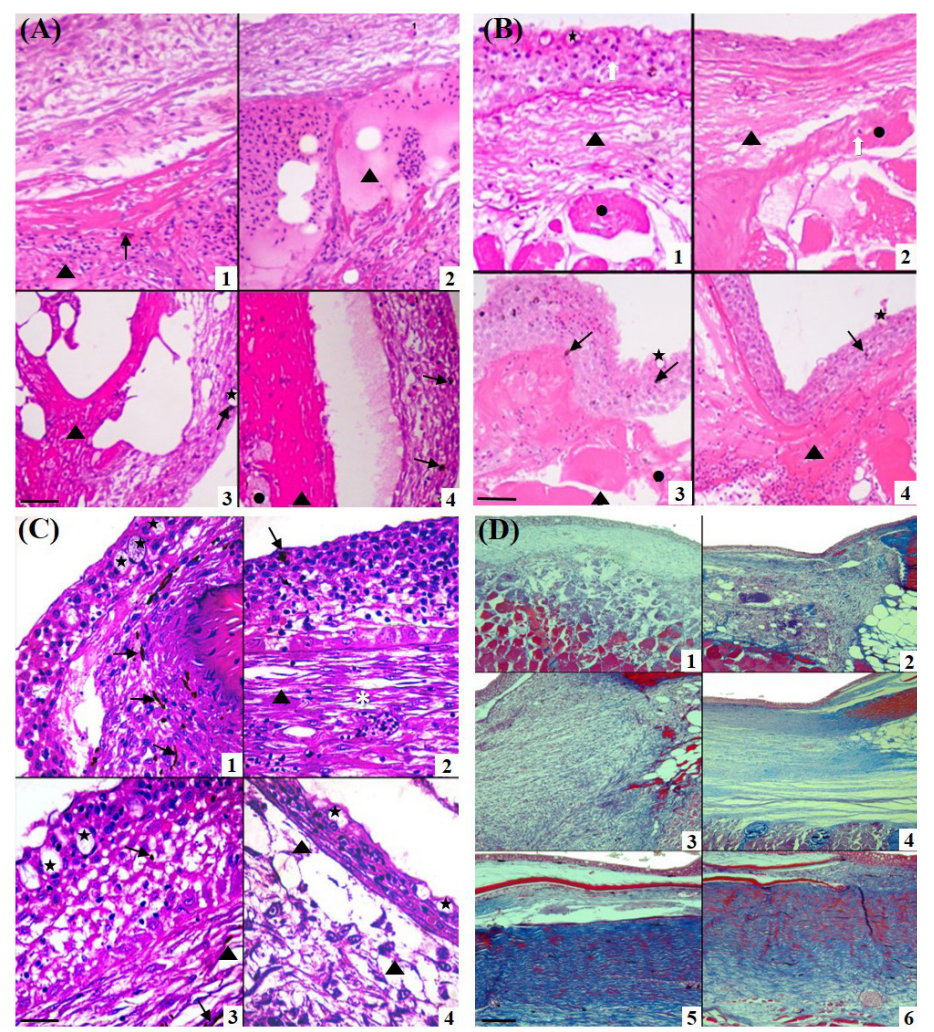

Figure 2 - Histopathology of skin after experimental wounding in Piaractus mesopotamicus nonsupplemented and supplemented with chromium carbochelate and Saccharomyces cerevisiae. (1) 1 day post injury (DPI): Control (a), SC (b), SC+CC (c), CC (d), staining H\&E. (2) 3 DPI: Control (a), SC+CC (c), CC (d), staining H\&E. (3) 7 DPI: Control (a), SC (b), SC+CC (c), CC (d), staining H\&E. Dissociation of structures (black triangle), muscular necrosis (black circle), chromatophores (black arrow), mucous cells (star), inflammatory cells (white arrow), and organization of collagen fibers (white asterisk). (4) Healing evolution at 1 DPI (a), 3 DPI (b), 7 DPI (c), 14 DPI (d), 21 DPI (e), and 35 DPI (f), staining Masson's Trichrome. Significant muscular necrosis in $a$ and $b$, progressive increase in number and organization of collagen fibers in $c, d, e, f$ 
$2 \mathrm{~B}$ ), as observed in skin injuries in common carp (IGER; ABRAHAM, 1990), Clarias batrachus (DUTTA; RAI, 1994), and P. mesopotamicus (MORAES et al. 2003). The predominant cells in inflammation sites regardless of time and group were macrophages, lymphocytes, and thrombocytes.

The number of inflammatory cells increased progressively until the third day in all groups, after which it started to decrease (Figure 3). Similar results were seen in the same species with no feed supplementation and supplementation with vitamin $\mathrm{C}$, in which the peak of inflammatory cells was achieved at 7 DPI (MORAES et al., 2003), indicating that the peak of inflammatory cells accumulation in the healing process of $P$. mesopotamicus occurs between these times. However, in non-supplemented tilapia and in tilapia supplemented with vitamin E, the peak occurs later, at 14 DPI (MORAES et al., 2011).

The number of leucocytes did not differ between groups ( $p>0.05$ ); however, it was significantly different between times ( $p<0.05$, Figure 3 ). Higher accumulation of inflammatory cells during early stage of healing (3 DPI) was observed in CC and in association groups when compared to control and SC groups. Early accumulation of inflammatory cells has also been observed during aerocystitis in fish supplemented with CC (CASTRO et al., 2014a, 2014b).

Accumulation of leukocytes in inflammatory focuses causes release of chemotactic and growth factors responsible for installing the microenvironment needed for granulation tissue (ACKERMANN, 2007). This stimulates neo-vascularization in the initial phase of the healing process, as observed in the present study at $7 \mathrm{DPI}$ $(\mathrm{p}<0.05$, Table 3$)$. Neovascularization during initial phase of wound healing is important for proper oxygen supply to the inflammatory process installed on site, removing cellular debris, inducing fibroplasia and protection against opportunistic agents (SILVA et al., 2005).

The inflammatory responses observed in all groups lead to dissociation of collagen fibers due to edema and mononuclear cell infiltration (Figure $2 \mathrm{D}$ ). Fibroblasts and collagen fibers were observed in all cases, though the degree of fiber organization was higher in the supplemented groups, similar to those observed in pacu supplemented with vitamin C (MORAES et al., 2003) and tilapia supplemented with vitamin $\mathrm{E}$ (MORAES et al., 2011).

The greater degree of fiber organization and higher amount of epithelial cells in supplemented groups were likely due to early accumulation of leukocytes in the injury and higher number of mucous and chromatophore cells (Figure 2A and C). Mucous cells play a crucial role as a mechanical and chemical barrier against different agents in fish skin (DALMO et al., 1997). Mucus is composed of lysozyme, lactoferrin, transferrin, components of the complement system, and immunoglobulins (KLESIUS et al., 2004). These features increase the resistance against secondary infections, improving wound healing.

Enhancements on general aspects of wound healing found in this study in the supplemented animals occurs

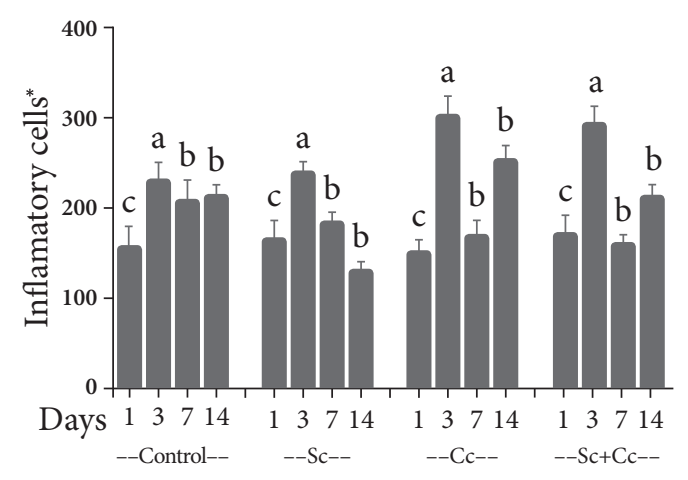

Figure 3 - Inflammatory cell accumulation in different treatments and sampling times after skin wound induction in Piaractus mesopotamicus non-supplemented and supplemented with chromium carbochelate and Saccharomyces cerevisiae. Different letters indicate significant differences by Tukey test $(\mathrm{p}<0.05)$ during different times of evaluation of the same group. ${ }^{\star}$ Number of inflammatory cells in five random fields on each slide $(n=12)$. Control: non-supplemented fish, SC: supplemented with $0.3 \%$ of S. cerevisiae, CC: supplemented with $18 \mathrm{mg} / \mathrm{kg}$ of chromium carbochelate, CC+SC: supplemented with both feed additives 
due to the enhancement of the initial phase of the healing process, which depends on the evolution of the inflammation for the debridement of tissue and decreases the load of opportunistic pathogens. Inflammation seems necessary for fibroblast recruitment, granulation-tissue formation, and wound vascularization both in mammals and fishes (RICHARDSON et al., 2013).

The improvement observed in animals supplemented with $S$. cerevisiae was attributed to the increased acute inflammation, nonspecific immune response, and better growth performance observed in fish supplemented with different fractions of $S$. cerevisiae (RODRÍGUEZ et al., 2003; ABDEL-TAWWAB et al., 2008; REQUE et al., 2010; SALVADOR et al., 2012, 2013).

The improvement of inflammatory response in fish supplemented with CC was likely due to the mechanism of action of chromium, which sensitizes insulin receptors on the cell surface, promoting higher input of this monosaccharide into the cells (MOWAT, 1997). At the same time, insulin acts as a pro-inflammatory hormone (MORAES; LEME, 1982; MORAES et al., 1987), then chromium could favor the development of inflammation increasing energy availability to meet demands from processes such as diapedesis and chemotaxis, resulting in greater cell accumulation in the inflammation focus (FUJIMOTO et al., 2005; CASTRO et al. 2014a, 2014b). In support of this hypothesis, the same authors found a reduction in levels of cortisol in animals supplemented with chromium carbochelate, suggesting a possible antistress effect (CASTRO et al., 2014a, 2014b).

\section{Conclusion}

The results indicate that dietary supplementation with chromium carbochelate, S. cerevisiae, and the association of both improves certain aspects of wound healing activity in pacu (P. mesopotamicus). Supplemented fish showed faster re-epithelialization, higher initial neovascularization, and greater degree of proliferation and organization of collagen fibers.

\section{Acknowledgements}

This work was funded by São Paulo Research Foundation (FAPESP) grant \#2007/58432-2 and scholarship \#2008/53179-0.

BANCROFT, J. D.; GAMBLE, M. Theory and practice of histological techniques. 5. ed. Edinburgh: Churchill Livingstone, 2002. 796 p.

BANERJEE, T. K.; MITTAL, A. K. Histopathological studies on the repair of the excised skin wounds of the air-breathing scalyfish Channa striata (Bloch). Current Science, v. 77, n. 8, p. 1067-1075, 1999.

ACKERMANN, M. R. Chronic inflammation and wound healing. In: MCGAVIN, M. D.; ZACHARY, J. F. (Eds.). Pathologic basis of veterinary disease. 4. ed. St. Louis: Mosby. 2007. p. 153-191.

AKHTER, N.; WU, B.; MEMON, A. M.; MOHSIN, M. Probiotics and prebiotics associated with aquaculture: a review. Fish \& Shellfish Immunology, v. 45, n. 2, p. 733-741, 2015. doi: 10.1016/j.fsi.2015.05.038.

ALKAHEM, H. F. The toxicity of nickel and the effects of sublethal levels on haematological parameters and behaviour of the fish, Oreochromis niloticus. Journal of University of Kuwait Science, v. 21, n. 2, p. 243-252, 1994.
BELO, M. A. A.; MORAES, J. R. E.; SOARES, V. E.; MARTINS, M. L.; BRUM, C. D.; MORAES, F. R. Vitamin $\mathrm{C}$ and endogenous cortisol in foreign-body inflammatory response in pacus. Pesquisa Agropecuária Brasileira, v. 47, n. 7, p. 1015-1021, 2012. doi: 10.1590/S0100204X2012000700019.

BOYD, C. E. Water quality in ponds for aquaculture. 2. ed. Auburn: Alabama Agricultural Experiment Station; Auburn University, 1990. 482 p.

CASTRO, M. P.; CLAUDIANO, G. S.; BORTOLUZZI, N. L.; GARRIDO, E.; FUJIMOTO, R. Y.; BELO, M. A. A.; 
SHIMADA, T. M.; MORAES, J. R. E.; MORAES, F. R. Chromium carbochelate dietary supplementation favored the glucocorticoid response during acute inflammation of Piaractus mesopotamicus. Aquaculture, v. 432, p. 114-118, 2014a. doi: 10.1016/j.aquaculture.2014.04.036.

CASTRO, M. P.; ClAUdiAnO, G. S.; PETRILlO, T. R.; SHIMADA, M. T.; BELO, M. A. A.; MARZOCCHIMACHADO, C. M.; MORAES, J. R. E.; MANRIQUE, W. G.; MORAES, F. R. Acute aerocystitis in Nile tilapia bred in net cages and supplemented with chromium carbochelate and Saccharomyces cerevisiae. Fish \& Shellfish Immunology, v. 36, n. 1, p. 284-290, 2014b. doi: 10.1016/j.fsi.2013.11.012.

DALMO, R. A.; INGEBRIGTSEN, K.; BØGWALD, J. Non-specific defence mechanisms in fish, with particular reference to the reticuloendothelial system (RES). Journal of Fish Diseases, v. 20, n. 4, p. 241-273, 1997. doi: 10.1046/j.1365-2761.1997.00302.x.

DAWOOD, M. A. O.; KOSHIO, S. Recent advances in the role of probiotics and prebiotics in carp aquaculture: a review. Aquaculture, v. 454, p. 243-251, 2016. doi: 10.1016/j.aquaculture.2015.12.033.

DUTTA, M.; RAI, A. K. Pattern of cutaneous wound healing in a live fish Clarias batrachus (L.) (Clariidae, Pisces.). Journal of the Indian Fisheries Association, v. 24, p. 107-113, 1994.

FUJIMOTO, R. Y.; CASTRO, M. P.; MORAES, F. R.; GONÇALVES, F. D. Efeito da suplementação alimentar com cromo trivalente em pacu, Piaractus mesopotamicus (Holmberg, 1887), mantido em diferentes densidades de estocagem: parâmetros fisiológicos. Boletim do Instituto de Pesca, v. 31, n. 2, p. 155-162, 2005.

GUERRA, R. R.; SANTOS, N. P.; CECARELLI, P.; SILVA, J. R. M. C.; HERNANDEZ-BLAZQUEZ, F. J. Healing of skin wounds in the African catfish Clarias gariepinus. Journal of Fish Biology, v. 73, n. 3, p. 572-583, 2008. doi: 10.1111/j.1095-8649.2008.01950.x.

IGER, Y.; ABRAHAM, M. The process of skin healing in experimentally wounded carp. Journal of Fish Biology, v. 36, n. 3, p. 421-437, 1990. doi: 10.1111/j.1095-8649.1990. tb05622.x.
KLESIUS, P. H.; EVANS, J. J.; SHOEMAKER, C. A. Warmwater fish vaccinology in catfish production. Animal Health Research Reviews, v. 5, n. 2, p. 305-311, 2004. doi: 10.1079/AHR200489.

LUKASKI, H. C. Magnesium, zinc, and chromium nutriture and physical activity. The American Journal of Clinical Nutrition, v. 72, n. 2, p. 585-593, 2000.

MORAES, F. R.; BECHARA, G. H.; MORAES, J. R. E. Effect of alloxan diabetes and adrenalectomy on carrageenininduced pleurisy in the rat. Brazilian Journal of Medical and Biological Research, v. 20, n. 1, p. 47-53, 1987.

MORAES, F. R.; LEME, J. G. Endogenous corticosteroids and insulin in acute inflammation. Microvascular Research, v. 23, n. 3, p. 281-293, 1982. doi: 10.1016/S00262862(82)80001-0.

MORAES, J. R. E.; FREITAS, J. B.; BOZZO, F. R.; MORAES, F. R.; MARTINS, M. L. A suplementação alimentar com vitamina $\mathrm{C}$ acelera a evolução do processo cicatricial em Piaractus mesopotamicus (Holmberg, 1887). Boletim do Instituto de Pesca, v. 29, n. 1 p. 57$67,2003$.

MORAES, J. R. E.; IWASHITA, M. K. P.; OZÓRIO, R. O. A.; REMA, P.; MORAES, F. R. Influence of vitamin E supplementation on dermal wound healing in Tilapia, Oreochromis niloticus. In: DE CARLO, F.; BASSANO, A. Freshwater ecosystems and aquaculture research. New York: Nova Science, 2011. p. 177-192.

MOWAT, D. N. Organic chromium in animal nutrition. Guelph: Chromium Books, 1997. 258 p.

NEIFFER, D. L.; STAMPER, M. A. Fish sedation, anesthesia, analgesia, and euthanasia: considerations, methods, and types of drugs. ILAR Journal, v. 50, n. 4, p. 343-360, 2009. doi: 10.1093/ilar.50.4.343.

PRZYBYLSKA-DIAZ, D. A.; SCHMIDT, J. G.; VERAJIMÉNEZ, N. I.; STEINHAGEN, D.; NIELSEN, M. E. $\beta$-glucan enriched bath directly stimulates the wound healing process in common carp (Cyprinus carpio L.). Fish \& Shellfish Immunology, v. 35, n. 3, 998-1006, 2013. doi: 10.1016/j.fsi.2013.05.014. 
QUILHAC, A.; SIRE, J.-Y. Spreading, proliferation, and differentiation of the epidermis after wounding a Cichlid fish, Hemichromis bimaculatus. The Anatomical Record, v. 254 , n. 3, p. 435-451, 1999. doi: 10.1002/(SICI)10970185(19990301)254:3<435::AID-AR15>3.0.CO;2-D.

RAI, A. K.; SRIVASTAVA, N.; NIGAM, A. K.; KUMARI, U.; MITTAL, S.; MITTAL, A. K. Response of the chromatophores in relation to the healing of skin wounds in an Indian Major Carp, Labeo rohita (Hamilton). Tissue and Cell, v. 44, n. 3, p. 143-150, 2012. doi: 10.1016/ j.tice.2012.01.003.

RAMASAMY, P.; SHANMUGAM, A. Characterization and wound healing property of collagen-chitosan film from Sepia kobiensis (Hoyle, 1885). International Journal of Biological Macromolecules, v. 74, p. 93-102, 2015. doi: 10.1016/j.ijbiomac.2014.11.034.

REQUE, V.R.;MORAES, J.R.E.;BELO, M.A.A.;MORAES, F. R. Inflammation induced by inactivated Aeromonas hydrophila in Nile tilapia fed diets supplemented with Saccharomyces cerevisiae. Aquaculture, v. 300, n. 1, p. 3742, 2010. doi: 10.1016/j.aquaculture.2009.12.014.

RICHARDSON, R.; SLANCHEV, K.; KRAUS, C.; KNYPHAUSEN, P.; EMING, S.; HAMMERSCHMIDT, M. Adult zebrafish as a model system for cutaneous woundhealing research. Journal of Investigative Dermatology, v. 133, n. 6, p. 1655-1665, 2013. doi: 10.1038/jid.2013.16.

RODRÍGUEZ, A.; CUESTA, A.; ORTUÑO, J.; ESTEBAN, M. A.; MESEGUER, J. Immunostimulant properties of a cell wall-modified whole Saccharomyces cerevisiae strain administered by diet to seabream (Sparus aurata L.). Veterinary Immunology and Immunopathology, v. 96, n. 3-4, p. 183-192, 2003. doi: 10.1016/j.vetimm.2003.07.001.

SALVADOR, R.; CLAUDIANO, G. S.; LOUREIRO, B. A.; MARCUSSO, P. F.; ETO, S. F.; PILARSKI, F.; TOAZZA, C. S.; MORAES, J. R. E.; MORAES, F. R. Desempenho e hematologia de tilápias-do-nilo alimentadas com dieta suplementada com Saccharomyces cerevisiae e vacinadas contra Streptococcus agalactiae. Pesquisa Agropecuária
Brasileira, v. 48, n. 8, p. 892-898, 2013. doi: 10.1590/S0100204X2013000800012.

SALVADOR, R.; TOAZZA, C. S.; MORAES, J. R. E.; MORAES, F. R. Inflammatory responses of Nile tilapia Oreochromis niloticus to Streptococcus agalactiae: effects of vaccination and yeast diet supplement. Disease of Aquatic Organisms, v. 98, n. 3, p. 235-241, 2012. doi: 10.3354/ dao02438.

SCHMIDT, J. G.; ANDERSEN, E. W.; ERSBØLL, B. K.; NIELSEN, M. E. Muscle wound healing in rainbow trout (Oncorhynchus mykiss). Fish \& Shellfish Immunology, v. 48, p. 273-284, 2016. doi: 10.1016/j.fsi.2015.12.010.

SILVA, J. R. M. C.; COOPER, E. L.; SINHORINI, I. L.; BORGES, J. C. S.; JENSCH-JUNIOR, B. E.; PORTO-NETO, L. R.; HERNANDEZ-BLAZQUEZ, F. J.; VELLUTINI, B. C.; PRESSINOTTI, L. N.; COSTA-PINTO, F. A. Microscopical study of experimental wound healing in Notothenia coriiceps (Cabeçuda) at $0^{\circ} \mathrm{C}$. Cell and Tissue Research, v. 321, n. 3, p. 401-410, 2005. doi: 10.1007/s00441-005-1139-z.

WAHLI, T.; VERLHAC, V.; GIRLING, P.; GABAUDAN, J.; AEBISCHER, C. Influence of dietary vitamin $C$ on the wound healing process in rainbow trout (Oncorhynchus mykiss). Aquaculture, v. 225, n. 1-4, p. 371-386, 2003. doi: 10.1016/S0044-8486(03)00302-8.

YUNIS-AGUINAGA， J.; CLAUDIANO, G. S.; MARCUSSO, P. F.; MANRIQUE, W. G.; MORAES, J. R. E.; MORAES, F. R.; FERNANDES, J. B. Uncaria tomentosa increases growth and immune activity in Oreochromis niloticus challenged with Streptococcus agalactiae. Fish \& Shellfish Immunology, v. 47, n. 1, p. 630-638, 2015. doi: 10.1016/j.fsi.2015.09.051.

YUNIS-AGUINAGA, J.; FERNANDES, D. C.; ETO, S. F.; CLAUDIANO, G. S.; MARCUSSO, P. F.; MARINHONETO, F. A.; FERNANDEZ, J. B. K.; MORAES, F. R.; MORAES, J. R. E. Dietary camu camu, Myrciaria dubia, enhances immunological response in Nile tilapia. Fish \& Shellfish Immunology, v. 58, p. 284-291, 2016. doi: 10.1016/j.fsi.2016.08.030. 